\title{
NON-CHEMICAL WEED MANAGEMENT IN POTATO AT HIGHER ELEVATIONS
}

\author{
HUSSAIN, Z. $^{1 *}-$ KHAN, M. A. ${ }^{1}-$ ILYAS, ${ }^{2}{ }^{2}-$ LUQMAN $^{1}-$ KHAN, I. A. $^{1}$ \\ ${ }^{1}$ Department of Weed Science, ${ }^{2}$ Department of Horticulture, \\ The University of Agriculture, 25130 Peshawar, Pakistan \\ *Corresponding author \\ e-mail: zhussainws@aup.edu.pk \\ (Received 27 $7^{\text {th }}$ Apr 2016; accepted 22 $2^{\text {nd }}$ Jul 2016)
}

\begin{abstract}
A field experiment was carried out at the Agriculture Research Station, Chitral, Pakistan in 2014 to determine the effect of sowing orientation, planting spacing and mulching on yield and weeds of potato crop, using a three factorial RCB design. The sowing orientation (Factor A) had two levels viz., north-south and east-west sowing, plant spacing (Factor B) with three levels of 15, 25 and $35 \mathrm{~cm}$, and mulching (Factor C) of Cannabis sativa L. biomass as mulch, Plantago lanceolata L. biomass as mulch along with a hand weeded treatment and a weedy control. The experiment results revealed a significant effect of sowing orientation, planting spacing, mulching and their interactions on the crop and weeds. The east-west sowing resulted in an increased weed density and biomass, whereas the north-south direction produced greater plant heights, greater number of leaves, tuber weight plant ${ }^{-1}$ and tuber yield. Plant spacing of $35 \mathrm{~cm}$ showed a significant increase in weed density and biomass, number of leaves and tubers plant $^{-1}$ and tuber weight plant ${ }^{-1}$. Plant spacing of $15 \mathrm{~cm}$ resulted in increased plant height and tuber yield. On the other hand, lowest weed density and biomass, number of leaves and tubers plant ${ }^{-1}$ and tuber weight were noted at planting space of $15 \mathrm{~cm}$. Among the treatments of factor $\mathrm{C}$, weedy check gave highest weed density and biomass ha ${ }^{-1}$ and plant heights, while the number of leaves and tubers plant ${ }^{-1}$, tuber weight plant ${ }^{-1}$ and yield ha ${ }^{-1}$ were the highest in hand weeding treatments. The weedy check showed lowest number of leaves and tubers plant ${ }^{-1}$, tuber weight plant $^{-1}$ and yield $\mathrm{ha}^{-1}$. In conclusion, the N-S sowing orientation, planting spacing of $15 \mathrm{~cm}$ and the mulching of plant biomasses of $C$. sativa and $P$. lanceolata proved the best combination for an environment-friendly weed management in potato at the higher elevations.
\end{abstract}

Keywords: Cannabis sativa, Plantago lanceolata, plant spacing, population, tuber yield, sowing orientation

\section{Introduction}

Potato is among the four major food crops grown in the world and three major vegetable crops in Pakistan. This tuber crop contains all the essential ingredients required for the maintenance of proper health. Pakistan has extensive edaphic and ecological resources for ideal potato production, which is grown in Pakistan on a diversified area, starting from sea level to an altitude of almost $3650 \mathrm{~m}$ in the mountains of northern areas. Potato is mostly affected by the infesting weeds that trigger substantial tuber yield reduction. Weeds significantly reduce the tuber yield whereas weed control treatments substantially increase the tuber yield as well (Jaiswal and Lal, 1996a, 1996b; Hussain et al., 2013; Mehring et al., 2016). Chemical control is the least expensive weed control method in potato that gives highest marginal return $(14.17 \%)$ as compared to other weed control methods (Jan et al., 2004). In case of no chemical use, hand weeding can help achieve highest potato yields (Hashim et al., 2003). Generally about Rs. (Pakistan rupees) 3 billions are annually lost due to weed competition, whereas 38\% yield losses are there in potato only (Hassan and Marwat, 2001). Yield losses in potato increase exponentially with increase in weeds biomass growing in the 
crop (Banaras, 1993; Mondani et al., 2011). In addition, weeds obstruct the tubers' harvesting (Knezevic et al., 1995). An estimated number of 8000 plant species are suspected to act as weeds, however, just 250 species are considered important for agriculture in the world. Environmental factors such as soil, light, water, temperature and micro-organisms do influence the weed range, their growth and distribution (Barbour et al., 1980; Peng, 1984).

An experiment was planned to assess the effect of certain environment-friendly weed control techniques to minimize the reliance on chemical weed control and boost healthy weed management tools. As the sunlight falls on the leaves in different angles in various regions around the globe, the idea was to examine the effect of sunlight when the crop is sown in east-west as well as north-south directions. A similar research was conducted by Steele et al. (2006) in USA who reported no effect of sowing orientation on potato crop. A second way of environment friendly weed management was the planting spacing which can improve the competition potential of potato plants with the growing weeds (Berkowitz, 1988; Forcella et al., 1992). Decreasing row spacing may also limit the period of time that weeds can compete with crops (Conley et al., 2001). In addition, mulching is another method through which the growing weeds can be suppressed helping the crop get more competitive (Bhullar et al., 2015). As organic crop production is appreciated worldwide (Khan et al., 2012) therefore, non-chemical weed management in vegetables needs to be explored. In this regard, various kinds of mulches have been tested worldwide; however, very little study has been conducted on weeds biomass using as mulch before their seeding stage for the purpose of shading the growing weeds in potato crop. This way we get two benefits in one attempt. Firstly the existing biomass of the infesting weeds is reduced through manual weeding and secondly the pre-seeding stage of the weed biomass is utilized for mulching purpose which helps shade or suffocate the emerging weeds that will eventually become a source of organic matter for soil in addition to weed management. There is definitely a dire need of developing a weed management strategy in potatoes which is more effective, sustainable, enhancing crop yields, environment-friendly and economical.

Therefore, keeping in view the above mentioned eco-friendly weed management techniques in potato, a field experiment was planned to assess the various non chemical weed control strategies for improvement in potato production and reduction in weeds infestation through environment friendly means.

\section{Materials and Methods}

\section{Experimental site and design}

The coordinates of the experimental site the Agriculture Research Station (Sheen Lasht) Chitral Pakistan are $35.8523^{\circ} \mathrm{N}, 71.7871^{\circ}$ E situated at an elevation of $1517 \mathrm{~m}$. The area of Chitral is 14850 square kilometers which is the largest district of Pakistan on basis of area. Chitral is having 76\% glaciers and mountains, $20 \%$ forests and grazing lands, and 4\% agricultural land. A field experiment was conducted during 2014 for studying the effect of row sowing directions (north-south and east-west sowing), various plant to plant spacings $(15,25$ and $35 \mathrm{~cm})$ and varying weed control treatments (including Cannabis sativa plant biomass and Plantago lanceolata plant biomass used as mulch, a hand weeding and a weedy check treatment) on yield and yield components of potato. The trial was performed in a three-factorial randomized complete block design replicated three times. 


\section{Agronomic practices}

Soil was ploughed thoroughly and then leveled using a cutter. The soil was of calcareous type having $\mathrm{pH}$ about 7.5-8. Well rotten farm yard manure was mixed with the soil. NPK was applied at 250, 125, $125 \mathrm{~kg} \mathrm{ha}^{-1}$, respectively. Irrigation was carried out with an interval of seven days. There were four ridges of potato crop in each subplot, each ridge $4 \mathrm{~m}$ long and spaced $0.75 \mathrm{~m}$ apart. Measurements were made on individual plants present in the mid two ridges of the four ridge plots. A local potato variety 'Rako' was sown in a plot size of $3 \mathrm{~m}$ by $4 \mathrm{~m}$ having 4 ridges (rows) each 4 meters long having $0.75 \mathrm{~m}$ row to row distance, making a total treatment size of $4 \mathrm{~m} \mathrm{x}$ $0.75 \mathrm{~m} \mathrm{x} 4=12 \mathrm{~m}^{2}$.

\section{Statistical analysis}

The collected data was analyzed through the statistical software Statistix 8.1 to generate ANOVA tables. The significant means were subjected to the LSD test. Graphs were generated using the MS-Excel in MS Office 2007. The mean factors are indicated in tables, whereas the significant interactions are presented in figures.

\section{Results}

\section{Weed density $\mathrm{m}^{-2}$}

There was a significant effect of sowing orientation, plant spacing, and weed control treatments on the density of weeds per square meter (Table 1). The weed density was found significantly lower (106 weeds $\mathrm{m}^{-2}$ ) in plots with potato plants sown in northsouth direction as compared to the sowing in east-west direction $\left(117 \mathrm{~m}^{-2}\right)$. Moreover, the number of weeds per unit area was significantly lowest $\left(104 \mathrm{~m}^{-2}\right)$ in planting spacing of $15 \mathrm{~cm}$, followed by plots in which potato plants were sown at a distance of $25 \mathrm{~cm}$ $\left(111.5\right.$ weeds $\left.\mathrm{m}^{-2}\right)$. The planting spacing of $35 \mathrm{~cm}$ exhibited the highest weed population $\left(119.6 \mathrm{~m}^{-2}\right)$. For the factor $\mathrm{C}$, the weed density was lowest $\left(69.2 \mathrm{~m}^{-2}\right)$ in hand weeded treatments followed by plots where Cannabis sativa plant biomass was used as mulch $\left(96.2 \mathrm{~m}^{-2}\right)$ and plots with plant biomass of Plantago spp. as mulch $\left(110.5 \mathrm{~m}^{-2}\right)$ as compared to the significantly highest weed density $\left(170.8 \mathrm{~m}^{-2}\right)$ in the weed check plots. The significant interaction for planting spacing and weed control treatments is given in Fig. 1.

\section{Weed biomass $\left(\mathrm{kg} \mathrm{ha}^{-1}\right)$}

There was a significant influence of sowing orientation, planting spacing, and weed control treatments on weed biomass (Table 1). Plots of potato grown in north-south direction resulted in lower weed biomass $\left(858 \mathrm{~kg} \mathrm{ha}^{-1}\right)$ as compared to sowing in the east-west direction $\left(940 \mathrm{~kg} \mathrm{ha}^{-1}\right)$. Weed biomass was significantly lowest $\left(728 \mathrm{~kg} \mathrm{ha}^{-1}\right)$ in plant spacing of $15 \mathrm{~cm}$, followed by plots in which potato plants were sown at a distance of $25 \mathrm{~cm}$ with weed biomass of $892 \mathrm{~kg} \mathrm{ha}^{-1}$. The highest weed biomass $(1,076$ $\mathrm{kg} \mathrm{ha}^{-1}$ ) was found in potato plant to plant distance of $35 \mathrm{~cm}$. The weed biomass for the weed control treatments was significantly lowest $\left(555 \mathrm{~kg} \mathrm{ha}^{-1}\right)$ in hand weeded plots, followed by plots of Cannabis sativa plant biomass as mulch (773 $\left.\mathrm{kg} \mathrm{ha}^{-1}\right)$ and Plantago sp. plant biomass applied as mulch $\left(882 \mathrm{~kg} \mathrm{ha}^{-1}\right)$. The weed biomass was 
significantly highest (1386 kg ha ${ }^{-1}$ ) in the control plots (weedy check). The significant interaction effect for $\mathrm{P} x \mathrm{~T}$ is given in Fig. 2.

Table 1. Effect of sowing orientation, plant spacing and weed control treatments on weed density $\mathrm{m}^{-2}$ and weed biomass $\left(\mathrm{kg} \mathrm{ha}^{-1}\right)$ in potato during 2014 at higher elevations of Pakistan

\begin{tabular}{|c|c|c|}
\hline Treatments & Weed density $\left(\mathrm{m}^{-2}\right)$ & $\begin{array}{l}\text { Weed biomass } \\
\left(\mathrm{kg} \mathrm{ha}^{-1}\right)\end{array}$ \\
\hline \multicolumn{3}{|l|}{ Sowing orientation $(S)$} \\
\hline East-west sowing (S1) & $117.1 \mathrm{a}$ & $940.32 \mathrm{a}$ \\
\hline North-south sowing (S2) & $106.2 \mathrm{~b}$ & $857.68 \mathrm{~b}$ \\
\hline Significance level & $*$ & $*$ \\
\hline \multicolumn{3}{|l|}{ Plant spacing $(P)$} \\
\hline $15 \mathrm{~cm}(\mathrm{P} 1)$ & $104.0 \mathrm{~b}$ & $728.3 \mathrm{c}$ \\
\hline $25 \mathrm{~cm}(\mathrm{P} 2)$ & $111.5 \mathrm{ab}$ & $892.2 \mathrm{~b}$ \\
\hline $35 \mathrm{~cm}(\mathrm{P} 3)$ & $119.6 \mathrm{a}$ & $1076.5 \mathrm{a}$ \\
\hline LSD $(0.05)$ & 12.3 & 96.70 \\
\hline \multicolumn{3}{|l|}{ Treatments $(T)$} \\
\hline Cannabis sativa biomass as mulch (T1) & $96.2 \mathrm{c}$ & $773.0 \mathrm{~b}$ \\
\hline Plantago spp. biomass as mulch (T2) & $110.5 b$ & $881.7 \mathrm{~b}$ \\
\hline Hand weeding (T3) & $69.2 \mathrm{~d}$ & $555.5 \mathrm{c}$ \\
\hline Weedy check (T4) & $170.8 \mathrm{a}$ & $1385.6 \mathrm{a}$ \\
\hline LSD (0.05) & 14.21 & 111.65 \\
\hline Interactions & \multicolumn{2}{|c|}{ Significance level } \\
\hline $\mathrm{S} \times \mathrm{P}$ & $\mathrm{Ns}$ & $\mathrm{ns}$ \\
\hline $\mathrm{S} \times \mathrm{T}$ & Ns & ns \\
\hline $\mathrm{P} \times \mathrm{T}$ & $*$ & $*$ \\
\hline $\mathrm{S} \times \mathrm{P} \times \mathrm{T}$ & Ns & ns \\
\hline
\end{tabular}

Means in the same column with different letters are significantly different at $\alpha=0.05$ using LSD test $*$ = Significant, $\mathrm{NS}=$ Non-Significant

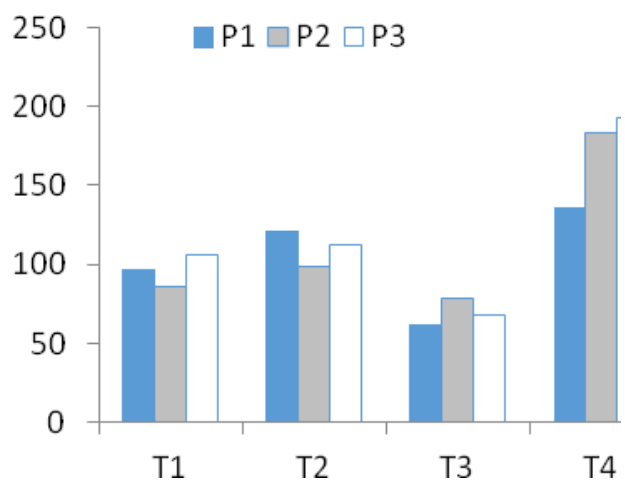

Figure 1. Interaction effect of plant spacing and weed control treatments $(P x$ T) for weed density $\mathrm{m}^{-2}$ in potato crop at higher elevation of Chitral during 2014

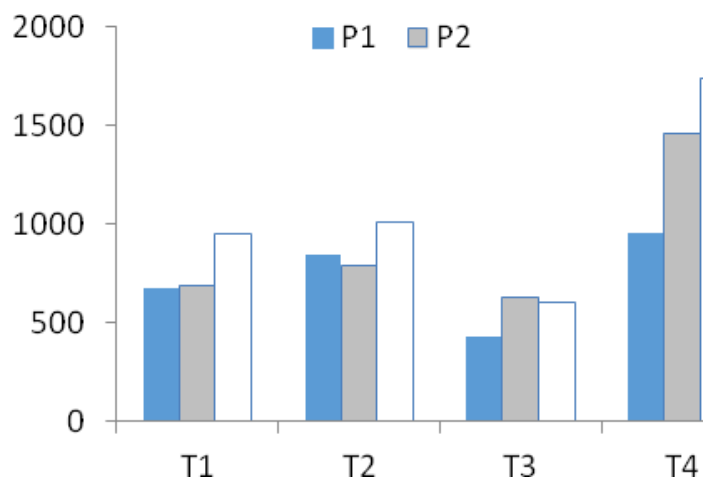

Figure 2. Interaction effect of plant spacing and weed control treatments $(P x$ T) for weed biomass $\mathrm{kg} \mathrm{ha}^{-1}$ in potato crop at higher elevation of Chitral during 2014 


\section{Potato plant height (cm)}

All the three factors and their interactions had a significant influence on potato plant height (Table 2). The plant height was lower $(46.5 \mathrm{~cm})$ in plots of east-west direction than in north-south $(51.5 \mathrm{~cm})$. As regards the plant spacing, potato plant height was lowest $(47.8 \mathrm{~cm})$ in $35 \mathrm{~cm}$ plant to plant spacing. It was followed by plots in which 25 $\mathrm{cm}$ spacing was maintained $(48.6 \mathrm{~cm})$. Highest potato plants $(50.6 \mathrm{~cm})$ were found at 15 $\mathrm{cm}$ plant-to-plant spacing. Among the weed control treatments, the plant height was significantly lowest $(43.43 \mathrm{~cm})$ in hand weeded plots followed by Cannabis sativa plant biomass used as mulch $(48.16 \mathrm{~cm})$ and plots with plant biomass of Plantago spp. applied as mulch $(50.03 \mathrm{~cm})$ as compared to the significantly highest plant height $(54.67$ $\mathrm{cm})$ in the weed check plots. The significant interactions are given in Figs. $3 a$ and $3 b$ for interactions of S x P and P x T, respectively.

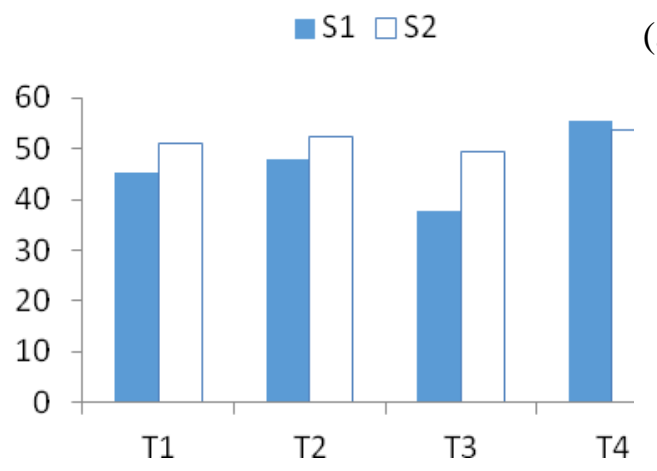

(a)

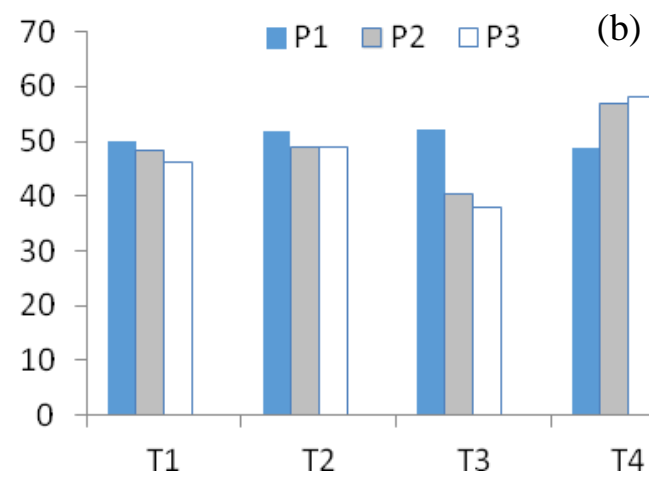

Figure 3. Interaction effect of (a) sowing orientation and weed control treatments $(S \times T)(b)$ plant spacing and weed control treatments $(P \times T)$ for plant height $(\mathrm{cm})$ of potato crop at higher elevation of Chitral Pakistan during 2014

\section{Number of leaves plant ${ }^{-1}$}

The analysis of the data showed that number of leaves plant $^{-1}$ was significantly affected by the studied factors (Table 2). There was smaller number of leaves plant ${ }^{-1}$ (20.47) in plots of east-west sowing orientation as compared to sowing in the northsouth (22.63). In plant spacing of $15 \mathrm{~cm}$, the number of leaves plant ${ }^{-1}$ was significantly lowest (17.6), followed by plots planting spacing of $25 \mathrm{~cm}$ (22.3 leaves). The number of leaves plant ${ }^{-1}$ was highest (24.7 leaves) in plant spacing of $35 \mathrm{~cm}$. The number of leaves plant $^{-1}$ was significantly lowest (15.2) in weedy check plots among the weed control treatments. Weedy check was followed by mulching of Cannabis sativa plant biomass (23) and of Plantago spp. plant biomass applied as mulch (21.3) as compared to the significantly highest number of leaves plant $^{-1}(26.5)$ in the hand weeded plots. The significant interaction for plant spacing $\mathrm{x}$ weed control treatments $(\mathrm{P} \times \mathrm{T})$ is given in Fig. 4.

\section{Tuber yield $\left(\mathrm{tha^{-1 }}\right)$}

After analyzing the data, it was found that the sowing orientation, plant spacing, and weed control treatments all significantly affected the tuber yield of potato. Table 2 indicated the mean values for potato tuber yield. The tuber yield was significantly 
higher $\left(19.58 \mathrm{t} \mathrm{ha}^{-1}\right)$ in plots of north-south row sowing as compared to row orientation of east-west sowing (18.11 t ha $\mathrm{ta}^{-1}$. In case of the plant spacing, the tuber yield was significantly highest $\left(20.00 \mathrm{t} \mathrm{ha}^{-1}\right)$ in plots of $15 \mathrm{~cm}$ spacing between potato plants. The highest tuber yield was followed by $18.80 \mathrm{t} \mathrm{ha}^{-1}$ where there was $25 \mathrm{~cm}$ spacing between potato plants; while the lowest tuber yield $\left(17.72 \mathrm{t} \mathrm{ha}^{-1}\right)$ was achieved in plant spacing of $35 \mathrm{~cm}$. The tuber yield was also significantly highest $\left(24.05 \mathrm{t} \mathrm{ha}^{-1}\right)$ in treatments of hand weeding which was followed by the mulching of Cannabis sativa plants $(20.22 \mathrm{t}$ $\mathrm{ha}^{-1}$ ) and mulching of Plantago sp. whole plants $\left(18.91 \mathrm{~m}^{-2}\right)$ as compared to the significantly lowest tuber yield of $12.18 \mathrm{t} \mathrm{ha}^{-1}$ in the control plots. Fig. 5 shows the significant interaction for plant spacing $\mathrm{x}$ weed control treatments $(\mathrm{P} \times \mathrm{T})$.

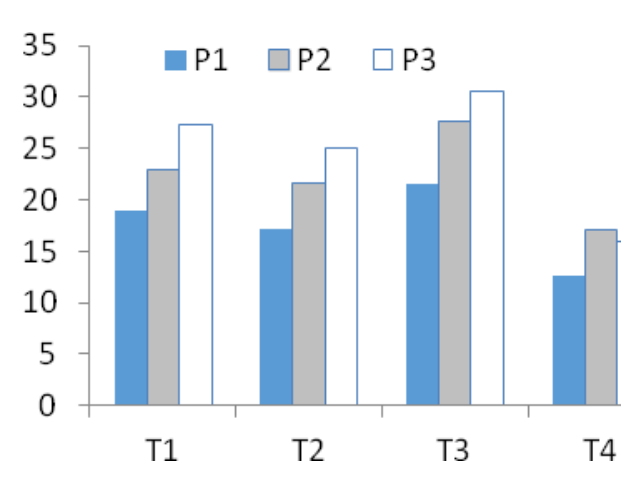

Figure 4. Interaction effect of plant spacing and weed control treatments $(P \times T)$ for number of leaves plant ${ }^{-1}$ potato crop at higher elevation of Chitral during 2014

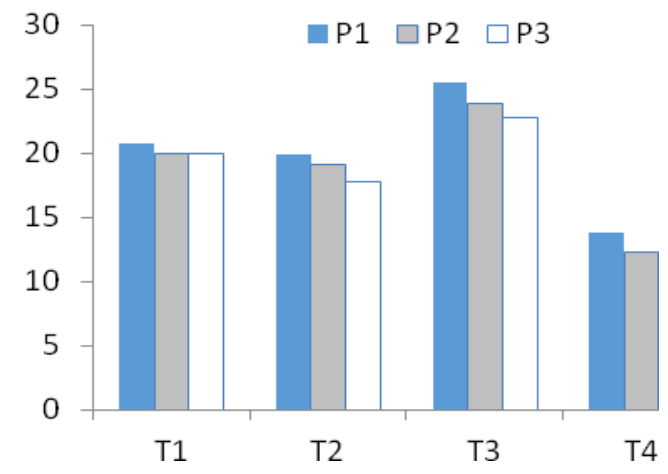

Figure 5. Interaction effect of plant spacing and weed control treatments $(P \times T)$ for tuber yield $\left(t h^{-1}\right)$ of potato crop at higher elevation of Chitral during 2014

Table 2. Effect of sowing orientation, plant spacing and weed control treatments on number of potato leaves plant ${ }^{-1}$ and tuber yield $\left(t \mathrm{ha}^{-1}\right)$ of potato crop during 2014 at higher elevations of Pakistan

\begin{tabular}{lccc}
\hline Treatments & $\begin{array}{c}\text { Potato plant } \\
\text { height }(\mathrm{cm})\end{array}$ & $\begin{array}{c}\text { Number of } \\
\text { leaves } \\
\text { plant }^{-1}\end{array}$ & $\begin{array}{c}\text { Tuber yield } \\
\left(\mathrm{t} \mathrm{ha}^{-1}\right)\end{array}$ \\
\hline Sowing orientation (S) & & & \\
\hline East-west sowing (S1) & $46.5 \mathrm{~b}$ & $20.47 \mathrm{~b}$ & $18.11 \mathrm{~b}$ \\
North-south sowing (S2) & $51.5 \mathrm{a}$ & $22.63 \mathrm{a}$ & $19.58 \mathrm{a}$ \\
\hline Significance level & $*$ & $* *$ & $* *$ \\
\hline Plant spacing (P) & & & \\
\hline $15 \mathrm{~cm}(\mathrm{P} 1)$ & $50.6 \mathrm{a}$ & $17.6 \mathrm{c}$ & $20.00 \mathrm{a}$ \\
$25 \mathrm{~cm}(\mathrm{P} 2)$ & $48.6 \mathrm{~b}$ & $22.3 \mathrm{~b}$ & $18.80 \mathrm{~b}$ \\
$35 \mathrm{~cm}(\mathrm{P} 3)$ & $47.8 \mathrm{~b}$ & $24.7 \mathrm{a}$ & $17.72 \mathrm{c}$ \\
\hline LSD (0.05) & 1.39 & 0.98 & 0.43 \\
\hline Treatments (T) & & & \\
\hline Cannabis sativa biomass as mulch (T1) & $48.16 \mathrm{c}$ & $23.0 \mathrm{~b}$ & $20.22 \mathrm{~b}$ \\
Plantago spp. biomass as mulch (T2) & $50.03 \mathrm{~b}$ & $21.3 \mathrm{c}$ & $18.91 \mathrm{c}$ \\
Hand weeding (T3) & $43.43 \mathrm{~d}$ & $26.5 \mathrm{a}$ & $24.05 \mathrm{a}$ \\
Weedy check (T4) & $54.67 \mathrm{a}$ & $15.2 \mathrm{~d}$ & $12.18 \mathrm{~d}$ \\
\hline LSD (0.05) & 1.61 & 1.13 & 0.50 \\
\hline
\end{tabular}




\begin{tabular}{lccc}
\hline Interactions & \multicolumn{3}{c}{ Significance level } \\
\hline $\mathrm{S} \times \mathrm{P}$ & $\mathrm{ns}$ & $\mathrm{ns}$ & $\mathrm{ns}$ \\
$\mathrm{S} \times \mathrm{T}$ & $*$ & $\mathrm{~ns}$ & $\mathrm{~ns}$ \\
$\mathrm{P} \times \mathrm{T}$ & $*$ & $*$ & $*$ \\
$\mathrm{~S} \times \mathrm{P} \times \mathrm{T}$ & $*$ & $\mathrm{~ns}$ & $\mathrm{~ns}$ \\
\hline
\end{tabular}

Means in the same column with different letters are significantly different at $\alpha=0.05$ using LSD test

$*$ = Significant, NS = Non-Significant

\section{Discussion}

\section{Weed density $\mathrm{m}^{-2}$}

The following weeds were recorded in the experimental field viz., Plantago lanceolata, Convolvulus arvensis, Chenopodium album, Cannabis sativa, Sorghum halepense, Polygonum aviculare, Cynodon dactylon and Veronica didama. The potato leaves received the solar radiation more effectively in the north-south sowing orientation as compared to the east-west sowing orientation due to which they became competent enough to suppress the emerging weeds. The canopy of the individual plants shades the adjacent plants in the east-west orientation of the potato rows (ridges) which may decrease the required solar radiation. Karanja et al. (2014) and Hozayn et al. (2012) reported significant effect of row sowing orientation on weed density and crop yield. The spaces between the potato plants significantly affected the weed density. Narrow spacing of $15 \mathrm{~cm}$ in potato plants suffocated weeds number per unit area whereas wider spacing ( 25 and $35 \mathrm{~cm}$ ) gave room to the growing weeds with which the number and composition of weeds increased (Conley et al., 2001; Ara et al., 2007).

Mulching enhances the soil moisture retention and improves soil temperature (Dalorima et al., 2014; Khan et al., 2012), which helps boost crop performance making the crop more competitive against the associated weeds. In addition, regardless of what kind of mulch is used, mulching of the soil causes a decrease in the weed density in the beginning of the growing period of vegetables like tomato, potato and onion (Kosterna, 2014). In the field trial, mulching of Cannabis sativa resulted better in declining the weed density due to its bigger canopy which effectively shaded the emerging weeds as compared to the mulching of Plantago spp. Though hand weeding resulted best in reducing the number of weeds per unit area, it is not feasible in conditions of labor scarcity, or at a large scale. The interaction effect of all factors was however nonsignificant except that for interaction of plant spacing and weed control treatments $(\mathrm{P} x$ $\mathrm{T})$. This indicated that $\mathrm{P} \times \mathrm{T}$ interaction is important for declining the weed density in potato crop of Chitral region of Pakistan.

\section{Weed biomass $\left(\mathrm{kg} \mathrm{ha}^{-1}\right)$}

Weed biomass is directly proportional to weed density i.e. the biomass is generally higher in plots with higher weed density. Here again the relatively efficient reception of solar radiation by the crop plants in the north-south oriented sowing made them get more competent against weeds as compared to the east-west sowing orientation. The planting spacing of potato plants significantly affected the weed biomass. As the narrow spacing of $15 \mathrm{~cm}$ among potato plants suffocated the weeds number per unit area due to which the weed biomass was eventually reduced. The wider spacing of 25 and $30 \mathrm{~cm}$ 
provided room for the growing weeds with which the number and biomass of weeds increased (Ara et al., 2007).

The weed control treatments also were effective in declining the weed biomass. Mulching treatments were effective in reducing weed biomass. It boosted the crop performance because of suppression of the associated weeds. Mulching of Cannabis sativa in this experiment performed well in resulting in reduced weed biomass due to the bigger canopy and shading of the emerging weeds. The interaction effect for plant spacing and treatments (PxT) was significant which represented that $\mathrm{P} \times \mathrm{T}$ interaction has got a key role in minimizing the weed biomass in potato crop.

\section{Potato plant height (cm)}

Plant height has got a complex phenomenon. It increases in circumstances of competition, particularly for receiving the sunlight. With increase in height the plant stem diameter decreases which indicates that it is not necessary that crop yield may linearly increase or decrease with plant height (Thornley, 1999). The significant difference in plant height of north-south and east-west sowing orientations showed that the competition for light is greater in the north-south direction as compared to east-west direction, in Chitral region of Pakistan. Close spacing of $15 \mathrm{~cm}$ increased potato plant height whereas wider spacing of 25 and $35 \mathrm{~cm}$ resulted in decreased plant height. The results are in harmony with those of Papadopoulos and Ormrod (1991) who recorded increase in plant height with close spacing. The height will increase with decrease in competition with weeds. In this connection, Mochiah et al. (2012) reported an increase in plant height of pepper with mulching of the soil. The mulching of Cannabis sativa effectively reduced the weed competition which eventually helps increase the plant height as compared to weedy check. The interaction effects for sowing orientation and planting spacing ( $\mathrm{S} \times \mathrm{P}$ ) were significant. This indicated that $\mathrm{S} \times \mathrm{P}$ interaction improved the plant height of potato grown at the higher elevation of Chitral Pakistan.

\section{Number of leaves plant ${ }^{-1}$}

The comparatively higher number of leaves plant ${ }^{-1}$ in the sowing orientation of north-south could be attributed to the more efficient reception of solar radiation as compared to that in the east-west sowing direction. The results for planting spacing were analogously reported by Zaag et al. (1990) who reported that wider spaces increase the branching of potato plants which enhances the number of leaves too. Regardless of what kind of mulch is used, mulching resulted in increased number of leaves plant ${ }^{-1}$ (Gudugi et al, 2012). The mulching of Cannabis sativa performed well in increasing the number of leaves plant ${ }^{-1}$ because of better plant height and less competition from weeds. The effect of plant spacing $\mathrm{x}$ treatments interaction was significant number of leaves plant $^{-1}$ in potato crop.

\section{Tuber yield ( $\left.\mathrm{ha}^{-1}\right)$}

Tuber yield of potato is the only parameter on which all the experiment is dependent upon. The north-south oriented crop resulted in better yield because of reduced weed density and biomass, and due to better plant height and number of leaves plant ${ }^{-1}$. In contrary to our results, Karanja et al. (2014) reported $18.3 \%$ increase in cowpea grain yields in east to west row orientated crops over the north to south oriented crops. Tsubo et al. (2004) also mentioned that E-W row oriented crops received higher 
photosynthetically active radiation (PAR) than the N-S ones. These contrary results could be justified as that E-W oriented crops receive higher PAR in at higher latitudes which happened in the experiments of Karanja et al. (2014) and Tsubo et al. (2004) in South Africa whereas N-S oriented crops receive higher PAR at lower latitudinal areas like Pakistan. The other reason could be Chitral, a region of higher altitude of Pakistan where N-S orientation would be more successful in terms of enhancement in competitive ability against weeds. Moreover, the canopy of individual crop plants overlap with the adjacent plants in E-W, consequently rendering the situation favorable for PAR reception in plots of N-S orientation. The plant to plant spacing in potato crop had a significant effect on the tuber yield of potato. Increasing the plant spacing from 15 $\mathrm{cm}$ to $35 \mathrm{~cm}$ decreased the per plant yield because of intra- specific competition among the crop plants but the gross yield was highest in the same plant spacing. Per hectare yield however decreased with increasing the plant spacing from 15 to $35 \mathrm{~cm}$. The results are in harmony with that of Ahmad and Singh (2005) who reported that even though the fruit size and the weight was higher in wider spaced rows, the total yield obtained was higher in the close spaced rows.

Among the weed control treatments, hand weeding provided best fruit yield as a result of efficient weed control. Hand weeding was however closely followed by mulching treatments of the selected weeds. The use of plant biomass of Cannabis sativa as mulch enhanced the yield of potato because of shading and eventual suppressing of the emerging weeds. Moreover, mulching of Plantago sp. was also better than the weedy check in significantly improving the potato tuber yield per hectare. The interaction between the plant spacing and weed control treatments was significant resulting in maximum tuber yield $\left(\mathrm{t} \mathrm{ha}^{-1}\right)$ in potato crop grown at the higher elevation.

\section{REFERENCES}

[1] Ahmad, A., Singh, A. (2005): Effects of Staking and Row-Spacing on the Yield of Tomato Cultivar "Roma VF" in the SokotoFadama, Nigeria. - Nigerian Journal of Horticultural Sciences 10: 94-98.

[2] Ara, N., Bashar, M.K., Begum, S., Kakon, S.S. (2007): Effect of spacing and stem pruning on the growth and yield of tomato. - International Journal of Sustainable Crop Production 2: 35-39.

[3] Banaras, M. (1993): Impact of weed competition on potato production. - Pakistan Journal of Agricultural Research 14: 64-71.

[4] Barbour, M.G, Burk, J.H., Pitts, W.D. (1980): Terrestrial Plant Ecology. Benjamin/Cummings Pub. Co., Menlo Park. California.

[5] Berkowitz, A.R. (1988): Chapter 7. - In: Weed Management in Agroecosysterns: Ecological Approaches. CRC Press, Boca Raton, FL. pp. 90-118.

[6] Bhullar, M.S., Kaur, S., Kaur, T., Jhala, A.J. (2015): Integrated weed management in potato using straw mulch and atrazine. - Horticultural Technology 25: 335-339.

[7] Conley S.P., Binning, L.I., Connell, T.R. (2001): Effect of cultivar, row spacing, and weed management on weed biomass, potato yield, and net crop value. - American Journal of Potato Research 78: 31-37.

[8] Dalorima, L.T., Bunu, A., Kyari, Z., Mohammed, T. (2014): Effects of different mulching materials on the growth performance of okra in Maiduguri. - International Research Journal of Agricultural and Soil Sciences 4: 145-149.

[9] Forcella, F., Westgate, M.E., Wames, D.D. (1992): Effects of row width on herbicide and cultivation requirements in row crops. - American Journal of Alternate Agriculture 7: 161-167. 
[10] Gudugi, I.A.S., Odofin, A., Adeboye, M.K., Oladiran, J.A. (2012): Agronomic characteristics of tomato as influenced by irrigation and mulching. - Advances in Applied Science Research 3: 2539-2543.

[11] Hashim, S., Marwat, K.B., Hassan, G. (2003): Chemical weed control efficiency in potato (Solanum tuberosum L.) under agro-climatic conditions of Peshawar, Pakistan. - Pakistan Journal of Weed Science Research 9: 105-110.

[12] Hassan, G., Marwat, K.B. (2001): Integrated weed management in agricultural crops. - Proc. National Workshop on technologies for Sustainable Agriculture, Sep. 24-26, 2001, NIAB, Faisalabad, Pakistan, Pp. 27-34.

[13] Hozayn, M., El-Shahawy, T.A.E.G., Sharara, F.A. (2012): Implication of Crop Row Orientation and Row Spacing for Controlling Weeds and Increasing Yield in Wheat. Australian Journal of Basic and Applied Sciences 6: 422-427.

[14] Hussain, Z., Munsif, F., Marwat, K.B., Ali, K., Afridi, R.A., Bibi, S. (2013): Studies on efficacy of different herbicides against weeds in potato crop in Peshawar. - Pakistan Journal of Botany 45: 487-491.

[15] Jaiswal, V.P., Lal, S.S. (1996a): Efficacy of cultural and chemical weed control methods in potato. - Journal of Indian Potato Association 23: 20-25.

[16] Jaiswal, V.P., Lal, S.S. (1996b): Efficacy of cultural and chemical weed-control methods in potato (Solanum tuberosum). - Indian Journal of Agronomy 41: 454-456.

[17] Jan, H., Muhammad, A., Ali, A. (2004): Studies on weed control in potato in Pakhal plains of Mansehra. - Pakistan Journal of Weed Sciences Research 10: 157-160.

[18] Karanja, S.M., Kibe1, A.M., Karogo, P.N., Mwangi, M. (2014): Effects of Intercrop Population Density and Row Orientation on Growth and Yields of Sorghum - Cowpea Cropping Systems in Semi Arid Rongai. - Kenyan Journal of Agricultural Sciences 6: 34-43.

[19] Khan, M.A., Marwat, K. B., Amin, A., Nawaz, A., Khan, H. (2012): Soil solarization: an organic weed management approach in cauliflower. - Communication in Soil Science and Plant Analysis 43 (13): 1847-1860.

[20] Kosterna, E. (2014): The effect of different types of straw mulches on weed-control in vegetables cultivation. - Journal of Ecological Engineering 15: 109-117.

[21] Knezevic, M., Durkic, M., Samota, D. (1995): Chemical and mechanical weed control in potatoes. - Fragmenta Phytomedica et Herbologica 23(2): 61-67.

[22] Mehring, G.H., Stenger, J.E., Hatterman-Valenti, H.M. (2016): Weed control with cover crops in irrigated potatoes. - Agronomy 6: 1-11. DOI 10.3390.

[23] Mochiah, M.B., Baidoo, P.K., Acheampong, G. (2012): Effect of mulching materials on agronomic characteristics, pests of pepper and their natural enemies' population. Agricultural and Biological Journal of North America 3: 253-261.

[24] Mondani, F., Golzardi, F., Ahmadvand, G., Ghorbani, R., Moradi, R. (2011): Influence of weed competition on potato growth, production and radiation use efficiency. - Notulae Scientia Biologicae 3: 42-52.

[25] Papadopoulos, A.P., Ormrod, D.P. (1991): Plant spacing effects on growth and development of the greenhouse tomato. - Canadian Journal of Plant Sciences 71: 297-304.

[26] Peng, S.Y. (1984): The biology and control of weeds in sugarcane. - Eslevier, Amsterdam, p. 25.

[27] Steele, D.D., Greenlanff, R.G., Hatterman-Valenti, H.M. (2006): Furrow vs hill planting of sprinkler-irrigated russet burbank potatoes on coarse-textured soils. - American Journal of Potato Research 83: 249-257.

[28] Thornley, J.H.M. (1999): Modelling stem height and diameter growth in plants. - Annals of Botany 84: 195-205.

[29] Tsubo, M., Mukhala, E., Ogindo, H.O., Walker, S. (2004): Productivity of maize-bean intercropping in a semi-arid region of South Africa. - Water South Africa 29: 381-388.

[30] Zaag, P.V., Demagante, A.L., Ewing, E.E. (1990): Influence of plant spacing on potato (Solanum tuberosum L.) morphology, growth and yield under two contrasting. Potato Research 33: 313-323. 